\title{
Investigation and Analysis on the Research of Engineering Students in Higher Vocational Level
}

\author{
Yumei Zhang ${ }^{1, *}$ Qingshan $\mathrm{Wu}^{2}$ Shiyi $\mathrm{Ju}^{3}$
}

\author{
${ }^{1}$ Binzhou Vocational College,School of Mechanical and Electrical Engineering, 256600 \\ ${ }^{2}$ Binzhou Vocational College,School of Mechanical and Electrical Engineering, 256600 \\ ${ }^{3}$ Nanyang Normal University, 473061 \\ *Corresponding author. Email: 13705438488@163.com
}

\begin{abstract}
This paper studies the present situation of students' textual research in higher vocational education, and uses big data to analyze the data through questionnaire, class actual interview, data collection and so on. According to the results, the proportion of academic certificate and professional skill certificate is obviously lower than that of qualification admission certificate, which is obviously contrary to the one $+X$ certificate policy issued by the state, and needs the school to strengthen the correct guidance.
\end{abstract}

Keywords: questionnaire survey, engineering students, Higher Vocational Level

\section{INTRODUCTION}

$1+X$ The introduction of the certificate system clarifies the development path of vocational education, which not only meets the basic requirements of social and economic development for academic qualifications, but also meets the requirements of social industry development for skills."Research fever" is widespread in colleges and universities, especially vocational colleges, the motivation of college students, whether there is really blind and overheated phenomenon? These are still worth exploring[3]This paper intends to select the students of HKUST as the research object and analyze the factors that affect the students' choice of textual research in order to understand the present situation of the students' textual research in higher vocational colleges.

\section{A SURVEY AND ANALYSIS OF STUDENTS' NEED FOR EXAMINATION}

\subsection{Sample selection}

This survey is divided into two stages, the first stage is to investigate the students' willingness to verify, after the data is processed, the second stage is to start the survey, and the second stage is to cross-analyze the factors that affect the research. In the last two months ,875 questionnaires were distributed ,817 valid questionnaires were collected, and the effective rate of the questionnaire was 93.4.

From the gender point of view, the sex ratio of male and female students was 90.5:9.5, which was in accordance with the norm of male and female students in engineering major. The average age of the subjects was about 19.5 years old.

\subsection{Students' willingness to study}

Among the factors affecting textual research, school factors account for the highest proportion, indicating that the construction of school style of study, the correct guidance of teachers play a key role, personal factors and social factors are not different, indicating that the factors affecting student textual research are unevenly distributed, family factors account for the least, only $10.40 \%$, indicating that college students desire independence and parents' influence is weakening.

\subsection{A description of the selected attitude of the surveyed sample}

According to Table 1, about $19.71 \%$ of the students did not have the will to study, $33.65 \%$ of the students were waiting to wait and see, $23.13 \%$ of the students said they were willing to try, and the proportion of students with strong desire to study.

Table 1 Selection of textual research

\begin{tabular}{|l|c|c|}
\hline The Research Will & Frequency & Percentage/\% \\
\hline No will & 161 & 19.71 \\
\hline Waiting to wait & 275 & 33.65 \\
Intent & 189 & 23.13 \\
\hline Already registered & 192 & 23.51 \\
\hline Total & 817 & 100 \\
\hline
\end{tabular}




\section{IMPACT OF PARENTS' EDUCATION ON STUDENTS' CHOICE OF TEXTUAL RESEARCH}

The communication with the children is less, and even the care for the children is not enough, which leads to the lack of clear development goals and active initiative. Parents' education level is high school or technical secondary school children, the strongest option is 71 people, accounting for 34.84. This part of the students are influenced by their parents and care very much about textual research and promotion, but the influence of society and surrounding is also very great. Parents are students with high school or above education level, the number of students without textual research intention is very small, only 2 people, accounting for $0.09 \%$, most of them have a positive attitude towards textual research promotion, most of them have strong intention and have signed up. Some students are waiting to wait and see. This further shows that parents' education level is closely related to rational choice, the higher the education level, the more reasonable the choice.

\section{INFLUENCE OF INDIVIDUAL FACTORS ON TEXTUAL RESEARCH SELECTION}

Table 2 shows that students generally lack confidence in textual research, or the difficulty of textual research. There are 271 students who think that cognitive reasons have a great influence on textual research, of which the proportion of waiting and watching options is the highest, accounting for $46.86 \%$. The other three options are basically flat, indicating that students are immature, prone to herd phenomenon, and lack of understanding of textual research policy.

Table 2 Students generally lack confidence in textual research, or the difficulty of textual research.

\begin{tabular}{|c|c|c|c|c|}
\hline \multirow{2}{*}{$\begin{array}{l}\text { Choice of } \\
\text { textual } \\
\text { research }\end{array}$} & \multicolumn{3}{|c|}{ Individual factors } & \multirow{2}{*}{ Total } \\
\hline & $\begin{array}{l}\text { Profess } \\
\text { ional } \\
\text { reasons }\end{array}$ & $\begin{array}{l}\text { Capacity } \\
\text { reasons }\end{array}$ & $\begin{array}{l}\text { Cognitive } \\
\text { causes }\end{array}$ & \\
\hline No will & 62 & 63 & 36 & 161 \\
\hline $\begin{array}{l}\text { Waiting } \\
\text { to wait }\end{array}$ & 91 & 57 & 127 & 275 \\
\hline Intent & 81 & 48 & 60 & 189 \\
\hline $\begin{array}{l}\text { Already } \\
\text { registere } \\
\text { d }\end{array}$ & 89 & 55 & 48 & 192 \\
\hline Total & 323 & 223 & 271 & 817 \\
\hline
\end{tabular}

\section{IMPACT OF FAMILY EDUCATION EXPENDITURE ON STUDENTS' CHOICE OF TEXTUAL RESEARCH}

Table 3 shows that, From the different family education annual expenditure on the choice of student textual research: no matter how much family education expenditure, The biggest wait - and - see, The highest percentage, This shows that young students are immature, The conformity is outstanding. In the option of strong will, The highest proportion of students with a family education expenditure of 20,000 to 30,000 yuan, To $27.56 \%$, The proportion of students with a family education expenditure of 30,000 to 40,000 was second, $25.00 \%$, It shows that children with high rational expenditure on family education choose more correctly, Desire to improve their competitiveness after textual research, (b) Reducing the burden on families; Students who spend more than $\$ 40,000$ on family education are basically flat, This shows that this part of the students have more distraction options, The desire to change the current state is low.

Table 3 Cross-Analysis of the Influence of Annual Expenditure on Educational Selection

\begin{tabular}{|l|c|c|c|c|c|}
\hline \multirow{2}{*}{$\begin{array}{c}\text { Choice } \\
\text { of textual } \\
\text { research }\end{array}$} & \multicolumn{3}{|c|}{$\begin{array}{c}\text { Household } \\
\text { expenditure/ } \$ 10,000\end{array}$} & \multirow{2}{*}{ Total } \\
\cline { 2 - 5 } & $2-3$ & $3-4$ & $4-5$ & 5 above & \\
\hline No will & 56 & 45 & 38 & 22 & 161 \\
\hline $\begin{array}{l}\text { Waiting to } \\
\text { wait }\end{array}$ & 89 & 55 & 74 & 57 & 275 \\
\hline $\begin{array}{l}\text { Intent } \\
\text { Already } \\
\text { registered }\end{array}$ & 81 & 46 & 41 & 24 & 192 \\
\hline \begin{tabular}{l} 
Total \\
\hline
\end{tabular} & 312 & 184 & 190 & 131 & 817 \\
\hline
\end{tabular}

\section{EFFECTS OF EMPLOYMENT STRESS ON STUDENTS' CHOICE OF EXAMINATIONS}

It can be seen from Table 4 that the perception of employment stress affects the choice of textual research :539 of the 817 students surveyed expressed employment stress, $65.97 \%$, Among them are waiting to wait and see and have signed up for a large number, 183 and 139 each, $33.95 \%$ and $25.79 \%$ respectively; 278 students surveyed said there was no job pressure, $34.03 \%$, There are more people waiting to see and willing, 92 and 76 each, The ratio was $33.09 \%$ and $27.34 \%$ respectively. Thus, Whether or not students feel the job pressure, The most waiting to see, In addition, the proportion of students who have no employment pressure is also high, Students with job pressure have signed up and are more willing, This shows that young students are positive about 
promoting themselves through textual research, Schools and teachers are needed to guide this group of students correctly, To help with career planning, Enhance its core competitiveness.

Table 4 Cross-Analysis of the Influence of Employment Stress Cognition on Textual Selection

\begin{tabular}{|c|c|c|c|}
\hline \multirow{2}{*}{$\begin{array}{c}\text { Choice of } \\
\text { textual research }\end{array}$} & \multicolumn{2}{|c|}{ Employment pressure } & \multirow{2}{*}{ Total } \\
\cline { 2 - 3 } & No & Yes & \\
\hline No will & 57 & 104 & 161 \\
\hline Waiting to wait & 92 & 183 & 275 \\
\hline Intent & 76 & 113 & 189 \\
\hline $\begin{array}{c}\text { Already } \\
\text { registered }\end{array}$ & 53 & 139 & 192 \\
\hline Total & 278 & 539 & 817 \\
\hline
\end{tabular}

\section{THE INFLUENCE OF RESEARCH POLICY UNDERSTANDING ON STUDENTS' RESEARCH CHOICE}

Table 5 shows that, About 344 students said they did not know anything about the policy, Forty-three students expressed an understanding of the policy. With "no idea" about policy, There were 123 people who chose not to, 35.76 per cent, Only 38 people have signed up, 11.05 per cent; With some knowledge of policy, Of the 38 people who chose not to, $8.03 \%$, Choose "signed up" for 154 people, As high as $32.56 \%$, This shows that the degree of understanding of the relevant policies is very important for students' behavior choice and judgment, Schools and relevant departments need to attach great importance to the promotion and popularization of policies. In addition, in this survey, The highest proportion of students waiting to wait and see, It also indirectly shows the importance of policy advocacy.

Table 5 Cross-Analysis Table on the Impact of Policy Understanding on Textual Selection

\begin{tabular}{|c|c|c|c|}
\hline \multirow{2}{*}{$\begin{array}{l}\text { Choice of textual } \\
\text { research }\end{array}$} & \multicolumn{2}{|l|}{ Level of policy awareness } & \multirow{2}{*}{ Total } \\
\cline { 2 - 3 } & Not at all & Know something & \\
\hline No will & 123 & 38 & 161 \\
\hline Waiting to wait & 111 & 164 & 275 \\
\hline Intent & 72 & 117 & 189 \\
\hline $\begin{array}{c}\text { Already } \\
\text { registered }\end{array}$ & 38 & 154 & 817 \\
\hline Total & 344 & 473 & \\
\hline
\end{tabular}

\section{THE INFLUENCE OF EXTERNAL FACTORS ON STUDENTS' CHOICE OF TEXTUAL RESEARCH}

Table 6 shows that, According to the analysis of the selection of textual research by external factors, the selection of family factors affects the selection of textual research, Of these 85 students, The proportion of options is similar, It shows that the influence of family factors on students' textual research is limited, Not the main factor; Of the 387 students selected by school factors, The "wait and see" and "strong will" options are the highest, $32.30 \%$ and $26.61 \%$, respectively, It shows that the school is a weak link in the propaganda of textual research policy and guiding students; Of the 312 students selected by social factors, There were 113 people waiting to see, 36.22 per cent, Far higher than the other three options, It shows that social research training, publicity and industry access have a great impact on students, Students are ambivalent, There is an urgent need for correct guidance.

Table 6 Cross-analysis table on the influence of external factors on students' textual research selection

\begin{tabular}{|c|c|c|c|c|}
\hline \multirow{2}{*}{$\begin{array}{l}\text { Choice of } \\
\text { textual } \\
\text { research }\end{array}$} & \multicolumn{3}{|c|}{ Influencing factors } & \multirow{2}{*}{ Total } \\
\hline & $\begin{array}{l}\text { Family } \\
\text { impact }\end{array}$ & $\begin{array}{l}\text { School } \\
\text { impact }\end{array}$ & $\begin{array}{l}\text { Social } \\
\text { impact }\end{array}$ & \\
\hline No will & 18 & 64 & 79 & 161 \\
\hline Waiting to & 37 & 125 & 113 & 275 \\
\hline Intent & 28 & 103 & 58 & 189 \\
\hline $\begin{array}{l}\text { Already } \\
\text { registered }\end{array}$ & 35 & 95 & 62 & 192 \\
\hline Total & 118 & 387 & 312 & 817 \\
\hline
\end{tabular}

\section{EFFECT OF "CERTIFICATE TYPE" RECOGNITION ON STUDENTS' CHOICE OF EXAMINATION}

Table 7 shows that, According to the analysis of the influence of "certificate type" on students' choice of textual research, $43.15 \%$ chose to wait and see, $30.00 \%$ of those who chose "signed up, Far higher than the other two options, It shows that the students' preference for the major is more polarized; Of the 399 students who tend to qualify for admission, $21.55 \%$ chose to wait and see, $25.31 \%$ chose "strong will, They're similar, The number of people who choose "no will" and "signed up" is the same, Explanation 1+X After the introduction of the policy, The importance of the certificate of professional skills has not yet been recognized by the social industry qualification certificate access attributes are still strong, (b) Still having a significant impact among young students; Of the students who tend to have academic credentials, The options are flat, It shows that students are not worried 
about obtaining academic certificates or that academic certificates have limited appeal to students. The share of academic and professional skills certificates is significantly lower than that of qualification certificates, And this is clearly contrary to $+\mathrm{X}$ national certification policy, The need for schools to strengthen correct guidance $^{[4]}$.

Table 7 According to the analysis of the influence of "certificate type" on students' choice of textual research

\begin{tabular}{|c|c|c|c|c|}
\hline \multirow{2}{*}{$\begin{array}{l}\text { Type of } \\
\text { certific } \\
\text { ate }\end{array}$} & \multicolumn{3}{|c|}{ Certificate Type Selection } & \multirow[b]{2}{*}{ Total } \\
\hline & $\begin{array}{l}\text { Certificate } \\
\text { of } \\
\text { Professional } \\
\text { Skills }\end{array}$ & $\begin{array}{l}\text { Qualifica } \\
\text { tion } \\
\text { Certifica } \\
\text { te }\end{array}$ & $\begin{array}{l}\text { Academic } \\
\text { Certificate }\end{array}$ & \\
\hline No will & 18 & 86 & 57 & 161 \\
\hline $\begin{array}{l}\text { Waiting } \\
\text { to wait }\end{array}$ & 69 & 134 & 72 & 275 \\
\hline Intent & 25 & 101 & 63 & 189 \\
\hline $\begin{array}{l}\text { Already } \\
\text { register } \\
\text { ed }\end{array}$ & 48 & 78 & 66 & 192 \\
\hline Total & 160 & 399 & 258 & 817 \\
\hline
\end{tabular}

\section{CONCLUSION}

School factors are the main factors affecting the choice of textual research, and schools are weak links in publicizing textual research policies and guiding students. Academic certificate and professional skill certificate account for obviously lower than qualification admission certificate, which is obviously contrary to the one $+X$ certificate policy issued by the state, and needs the school to strengthen the correct guidance[2]。

" $1+X "$ The introduction and implementation of the certificate policy has pointed out the direction for the future development of vocational education and the cultivation of talents in vocational colleges and universities. Schools need to strengthen professional construction, do a good job of textual research policy publicity and related training, cultivate students' professional interest, improve students' core competitiveness, and higher technical and applied talents to meet the needs of society.

\section{REFERENCES}

[1] Cho - Yeon. Analysis on the Current Situation of "Examination Fever" J]. Students in Higher Vocational Colleges Think tank era ,2019, (7):128-130.

[2] Tan Kai. "1+x" Analysis of the impact of the Certification Scheme [J].]; and Science and Technology Economic Guide 17(27):144-145.

[3] du Yuejia, Zhang Zihao. Cold Thoughts on the Phenomenon of "Heat in Examination" J]. College Students Law and Society 1(middle):157-159.

[4] Xu Juan. A Study on the "Hot Research" of Students in Higher Vocational Colleges [J].]; and Journal of Lanzhou Institute of Education ,2017(6):107-109. 